\title{
A Continuous Distribution Model to Predict a Long-term Selection Response Taking the Effect of Reproduction into Account
}

\author{
Akira Nishida, Yoshitaka Nagamine* ${ }^{*}$ Katsuhiro MiURA \\ and Masahiro $\mathrm{SATOH}_{\mathrm{A}}$ \\ National Institute of Animal Industry, Tsukuba Norindanchi, \\ Ibaraki-ken 305 \\ * Tohoku National Agricultural Experiment Station, \\ Morioka-shi 020-01
}

(Received December 21, 1987)

\begin{abstract}
The present study was undertaken with the purpose of developing a more practical model for the prediction of a long-term seletion response. Following a discontinuous distribution model previously derived, a continuous distribution model to predict a long-term selection response for one trait was developed, taking the effects of reproduction into account. The continuous distribution model requires more simple and practical assumptions than the discontinuous distribution model. This model for a one trait selection can be expanded into a model for index selection concerned with more than two traits genetically correlated.
\end{abstract}

Jpn. J. Zootech. Sci., $59(6): 548-553,1988$

Key words : prediction model, long-term selection, selection response

In the previous stdies ${ }^{1-5)}$ on a theoretical model to predict a long-term selection response, all the genetic properties were assumed to be the same in the selected parents and their progeny in order to simplify the subject. However, the genetic properties of the selected parents are changed by reproduction even under random mating ${ }^{6)}$.

TAKEDA et $a l^{7)}$ developed a discontinuous distribution model to predict a longterm selection response which took the effect of reproduction into account to obtain the higher accuracy of prediction.

The present study was carried out in an attempt to develop a more practical continuous distribution model based on more simple and smaller number of assumptions.

\section{Theory}

The continuous distribution model is based on the assumption that the variables are distributed continuousely within an assigned range. The model consists of the following procedures.

(1) Estimation of the distribution in breeding value (G).

(2) Retroactive development of the distribution in $G$ into the joint distribution 


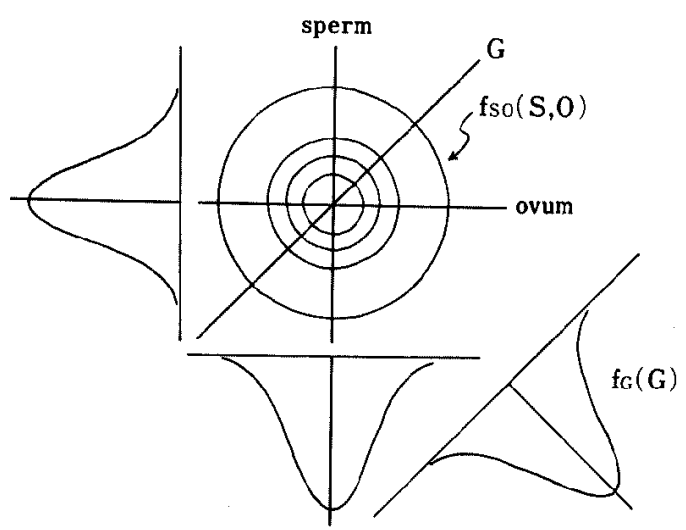

Fig. 1. Retroactive development of the distribution in breeding value $\mathrm{f}_{\mathrm{G}}(\mathrm{G})$ into the joint distribution with genetic values of the sperm and the ovum $f_{s o}(S, O)$ coupled to make the $f_{G}(G)$.

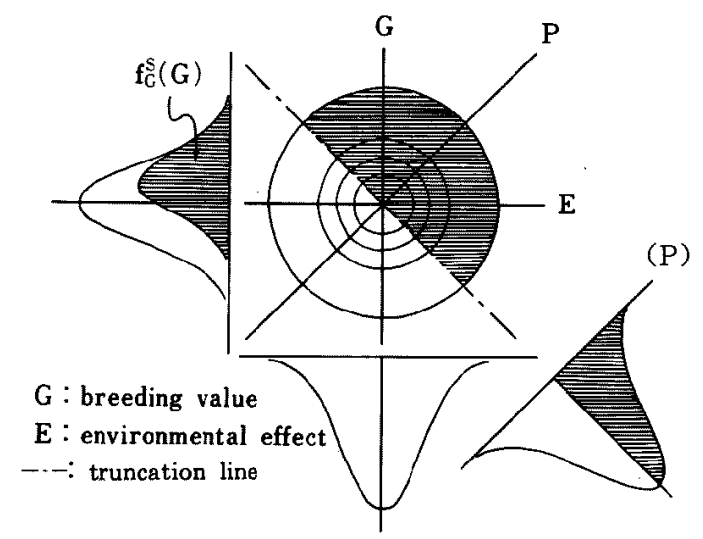

Fig. 2. Truncation selection based on phenotypic value $P$ and evaluation of the marginal distribution in $G$ for the selected part (shadowed area) $f_{G}^{S}(G)$.

with additive genetic values of the sperm $(S)$ and the ovum $(O), f_{\text {so }}(S, O)$ coupled to make the G (Fig. 1).

(3) Truncation selection based on phenotypic value (P) and evaluation of the marginal distribution in $G$ for the selected part (Fig. 2).

(4) Gametogenesis by the selected animals (Fig. 3).

(5) Generation of new distribution in $\mathrm{G}$ by random mating of the selected animals (Fig. 4).

(6) Evaluation of the distribution in $P$.

The replicated use of the above procedures from (3) to (6) enables us to predict the long-term selection response. 


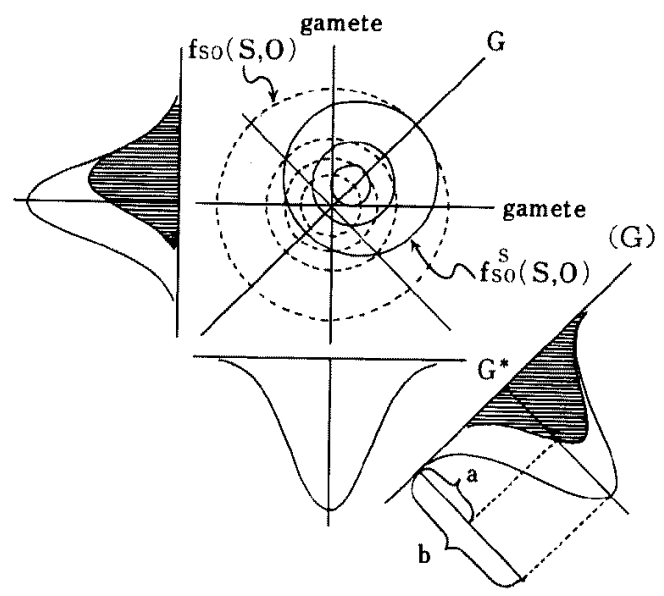

Fig. 3. Gametogenesis by the selected animals

$a / b$ : the proportion of selection at $G=G^{*}$, $\mathrm{f}_{\mathrm{G}}^{\mathrm{s}}\left(\mathrm{G}^{*}\right) / \mathrm{f}_{\mathrm{G}}\left(\mathrm{G}^{*}\right)$, contours with dotted lines: contours of $\mathrm{f}_{\mathrm{SO}}(\mathrm{S}, \mathrm{O})$ in the base population, contours with solid lines: contours of the selected part $\mathrm{f}_{\mathrm{SO}}^{\mathrm{S}}(\mathrm{S}, \mathrm{O})$ (shadowed area).

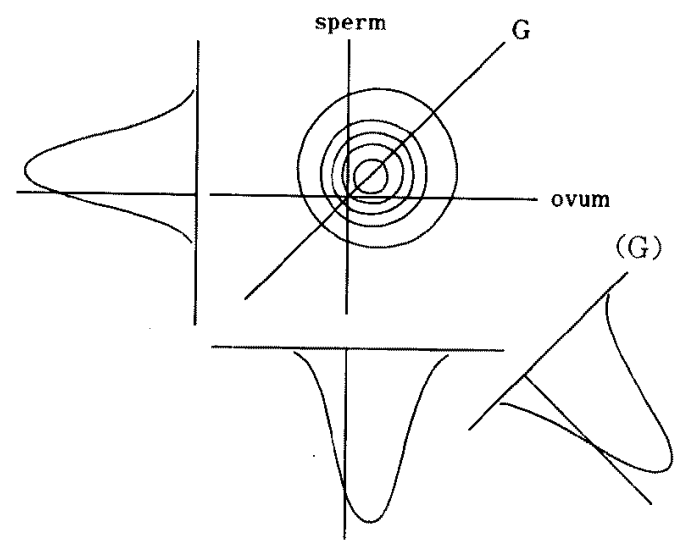

Fig. 4. Generation of a new distribution in breeding value $G$ by random mating of the selected animals.

Since the figures are drawn as the proportion of selection is $1 / 2$, the frequencies of the gametes are multiplied by 2 in this example for the restoration of the population size. This means the proliferation of the selected animals to keep the population size constant. 


\section{Prediction Model of Long-term Selection Response}

The contents of the procedures

(1) Estimation of the distribution in G

As a first step, the distribution in $G$ has to be estimated. If the normality of the distribution in the environmental effect (E) is properly assumed, the distribution in $G$ is estimable from the distribution in $P$. We are now studying a method to estimate the disribution in $G$ directly from the properties of the base population without the normality assumption in $\mathrm{E}$.

(2) Retroactive development of the distribution in $G$ into $f_{S O}(S, O)$

A coordinate system defined by the axis of ordinates for $S$ and abscissas for $O$ is introduced (Fig. 1). In this system, the axis for $G$ is derived by the following operations.

1) Counterclockwise rotation of $O$ axis around the origin at an angle of $\pi / 4$ radian. This gives

$\mathrm{O}^{\prime}=\mathrm{S} \sin (\pi / 4)+\mathrm{O} \cos (\pi / 4)=\frac{1}{\sqrt{2}}(\mathrm{~S}+\mathrm{O})$.

2) Scale transformation which converts one unit of length on $O$ axis to $\sqrt{2}$ unit on the new axis. This results in $\sqrt{2} \mathrm{O}^{\prime}=\mathrm{S}+\mathrm{O}=\mathrm{G}$.

On this coordinate system, if we assume the equality of the distributions in $S$ and $O$ and random coupling of them to make the base population, the distribution in $G$ on $G$ axis can be developed into $f_{\text {so }}(S, O)$ which has circular contour lines with the centers on $\mathrm{G}$ axis.

(3) Truncation selection based on $P$ and evaluation of the marginal distribution in $G$ for the selected part

The detailed explanation on this procedure has been given in the previous report $^{1)}$ (Fig. 2).

(4) Gametogenesis by the selected animals

To begin with, the proportion of selection at $G=G^{*}, f_{G}^{S}\left(G^{*}\right) / f_{G}\left(G^{*}\right)$ is calculated where $f_{G}\left(G^{*}\right)$ is the frequency of $G^{*}$ in the population of the previous generation and $f_{G}^{S}\left(G^{*}\right)$ means the frequency of the selected part (Fig. 3). The product of the conditional frequency distribution $f_{S O}(S, O)$ when $G=G^{*}$ and the proportion of selection obtained above gives the joint distribution with $\mathrm{S}$ and $\mathrm{O}$ coupled to make the selected part of the population at $\mathrm{G}=\mathrm{G}^{*}$. This operation is written as follows ;

$$
\left(f_{S O}^{S}(S, O) \mid G=G^{*}\right)=\left(f_{S O}(S, O) \mid G=G^{*}\right) \cdot f_{G}^{S}\left(G^{*}\right) / f_{G}\left(G^{*}\right)
$$

where

$$
\begin{aligned}
\left(f_{S O}(S, O) \mid G=G^{*}\right): & \text { conditional frequency distribution of } f_{S O}(S, O) \text { at } \\
& G=G^{*} \text { coupled to make the population of the } \\
& \text { previous generation } \\
& : \text { frequency of } G^{*} \text { in the population of the previous } \\
& \text { generation } \\
f_{G}\left(G^{*}\right) \quad & \text { frequency on the selected part of the distribution. }
\end{aligned}
$$

This operation is applied to the whole range of $G$ and the whole joint distribution with $S$ and $O$ coupled to make the selected part of the population, 
$\mathrm{f}_{\mathrm{SO}}^{\mathrm{S}}(\mathrm{S}, \mathrm{O})$, is obtained.

Projection of $\mathrm{f}_{\mathrm{SO}}^{\mathrm{S}}(\mathrm{S}, \mathrm{O})$ to the abscissas and the ordinates brings the distribution in genetic value of gamete generated by the selected animals (Fig. 3).

(5) Generation of a new distribution in $G$ by random mating of the selected animals

This procedure contains the evaluation of joint distribution by the random coupling of sperm and ovum from the selected animals and the projection of the joint distribution to $\mathrm{G}$ axis (Fig. 4).

(6) Evaluation of the new distribution in $P$

The explanation has been given in the previous report ${ }^{13}$.

The replicated use of the procedures from (3) to (6) is necessary for the prediction of a long-term selection response.

\section{Discussion}

The discontinuous distribution model requires many assumptions on the number of loci concerned, number of alleles in each locus, effects of allelic genes and their initial frequencies in each locus. From a practical point of view, it is difficult to prepare an adequate set of assumptions on the above items. However, if we could assume these, the given parameters automatically decide a selection limit as their function.

On the other hand, in the continuous distribution model, necessary assumptions are much simpler and more practical but the selection limit has to be estimated independently ${ }^{8,9}$.

This continuous distribution model for one trait selection can be expanded into a model for index selection concerned with more than two traits genetically correlated.

\section{Refercences}

1) Nishida, A. and T. AbE, Jpn. J. Zootech. Sci., 51 : 485-494. 1980.

2) NishidA, A. and T. ABE, Jpn. J. Zootech. Sci., 51: 495-500. 1980.

3) Nishida, A. and T. HAYASHI, Jpn. J. Zootech. Sci., 51 : 745-747. 1980.

4) Nishida, A., T. Hayashi and Y. Nagamine, Jpn. J. Zootech. Sci., 54: 239-244. 1983.

5) Nishida, A., T. Hayashi and Y. Nagamine, Jpn. J. Zootech. Sci., 55 : 350-355. 1984.

6) Robertson, A., Z. Tierzuchtg. Zuchtgsbiol., 94 : 131-135. 1977.

7) TAKedA. H., A. TAKebe, A. NishidA, Jpn. J. Zootech. Sci., 59: 554-559. 1988.

8) Robertson, A., Proc. Roy. Soc. London, B 153: 234-249. 1960.

9) Hill. W.G. and J. RAsBash, Genet. Res. Camb., $48:$ 41-50. 1986. 


\title{
連続分布を用い繁殖の影響を考慮した 長期選抜効果の予測モデル
}

\author{
西田 朗・長嶺慶隆* 三 三浦克洋・佐藤正寛
}

農林水産省畜産試験場, 茨城県筑波農林研究団地 305

* 農林水産省東北農業試験場，盛岡市 020-01

長期的な選抜の効果を予测するための，実際的なモデ ルを作ることを目的として研究を行なった，前報におい て導いた不連続分布を用いるモデルに続いて, 本報では, より単純で現実的な仮定に立脚して，連続分布を用い繁
殖の影響を考慮した予測モデルを組立てた。この一形 質の選抜に関するモデルは，2つ以上の形質を含む指数 選抜にも拡張して適用できる。

日畜会報, $59(6): 548-553,1988$ 